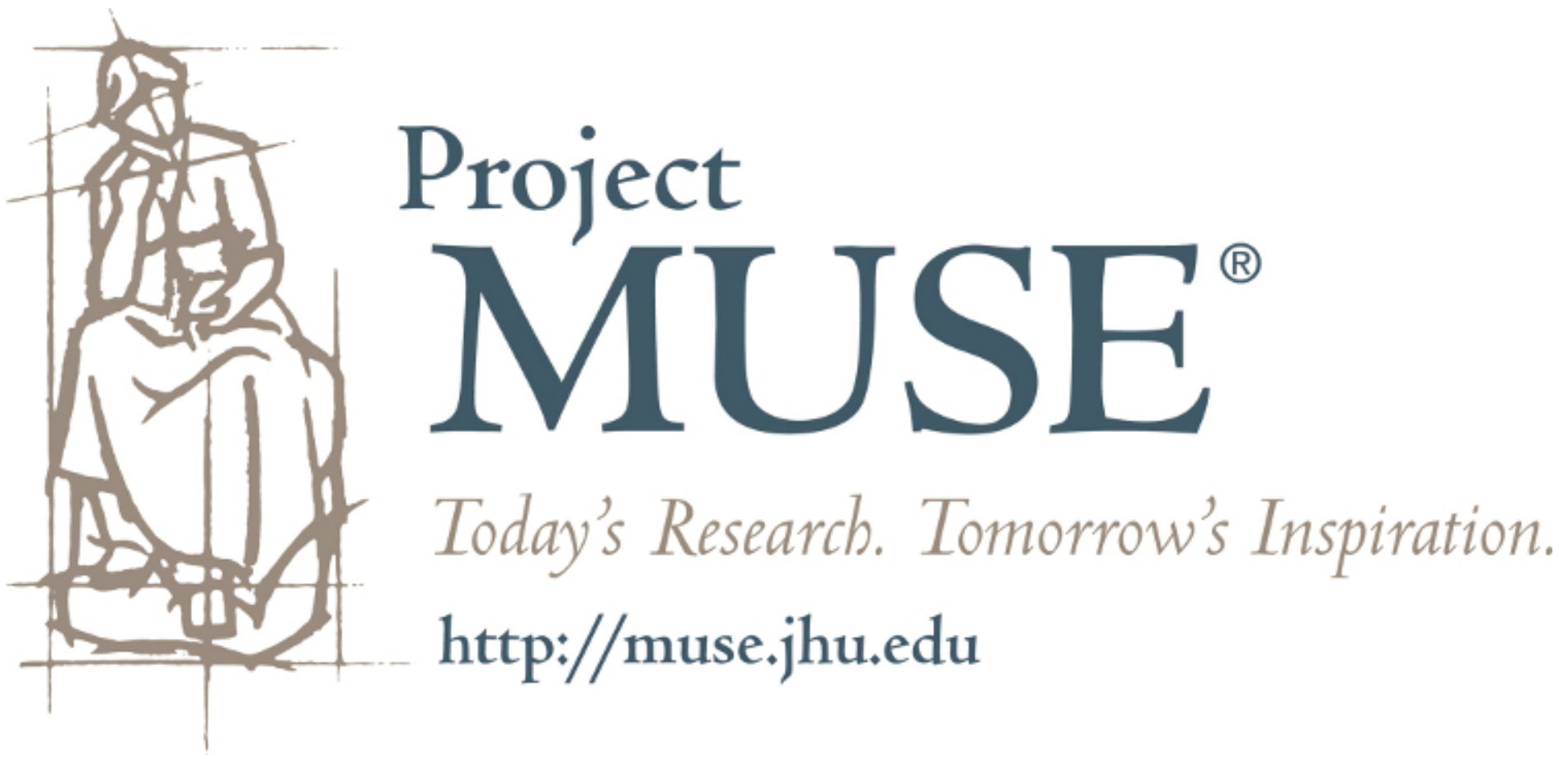




\title{
History, Poetry, and the Footnote: Cleanth Brooks and Kenneth Burke on Keats's "Ode on a Grecian Urn"
}

\author{
Dries Vrijders
}

I

N THE SUMMER OF 1943, two literary scholars were working on Keats's "Ode on a Grecian Urn." Kenneth Burke's "Symbolic Action in a Poem by Keats" appeared first, in the autumn edition of Accent; Cleanth Brooks published his "History without Footnotes: An Account of Keats' Urn" just a few months later in the Sewanee Review. Obviously embarrassed by the peculiar concurrence, Brooks added a note to his essay, in which he admits having come upon Burke's some months after having completed his own. Yet despite the many similarities between both, Brooks says, he had resisted the urge to make alterations. Rather, he writes, "I am happy to find that two critics with methods and purposes so different should agree so thoroughly as we do on the poem. I am pleased, for my part, therefore, to acknowledge the amount of duplication which exists between the two essays, counting it as rather important corroboration of a view of the poem which will probably seem to some critics overingenious" (89). ${ }^{1}$ Coming across a footnote that disrupts the confident tone and wholeness of execution that usually characterize Brooks's writing is a notable occasion in itself, but its appearance in an essay whose very title condemns the practice of adding them is striking to the point of bewilderment. Yet despite the large amount of scholarly response Brooks's essay has received, the reference has been largely neglected. Reprinted as "Keats's Sylvan Historian: History without Footnotes," the essay became widely anthologized as the key to Brooks's brilliant classic The Well Wrought Urn; Burke's reading of the ode, on the other hand, went the way of the footnote, sliding almost unobtrusively from the margins of the page to the edges of history. ${ }^{2}$

To a considerable extent, Brooks himself can be held responsible for the apparent ease with which we have omitted part of his essay from our comments. If historians needs footnotes as forensic evidence that their accounts are supported by sufficient amounts of study devoted to incontestable sources, Brooks's essay upholds that literary criticism moves on different — and ultimately more truthful—grounds of legitimacy. Thus 
stripped of their authoritative weight, footnotes degenerate into gathering places for critical debris, short references or digressions that do not permeate the main body of the text. In its staunch depreciation of the historical and philological devices that claim to summon the material and referential dimensions of the text, "History without Footnotes" has persuaded generations of critics that literature can be engaged without having to take recourse to such secondary levels of discourse. However, I will argue, the imposing presence of its ahistorical hermeneutic and its enmity towards the footnote as a legitimate device for the literary critic have severely hampered our understanding of a vital part of the essay's critical politics. As Antony Grafton points out, besides their more obvious role as mediators between the historian's account and the evidence that supports it, footnotes often serve as a way of professing one's allegiance to a particular guild of scholars rather than another. Every historiographic act entails a battle of inclusion and omission that is waged-more vehemently still than in the main textual body-at the edges of the page, where the space (or absence thereof) devoted to other scholars or sources signals one's accordance to a given set of intellectual or methodological principles rather than another. ${ }^{3}$

As I will demonstrate, Brooks's footnote about "Symbolic Action in an Essay by Keats" should be read as such a rhetorically laden reference, one through which the distinctive line of formalist criticism Burke develops is both appropriated and contained. I argue that the controversial line of aesthetic historicism that Brooks sought to develop through his reading of Keats's ode forced him to seek Burke's allegiance, but that, at the same time, the definite historist tendencies of Burke's reading required it to be quarantined in the purgatory of the footnote rather than the main text. ${ }^{4}$ The comparative method of reading I employ to map the force lines underlying Brooks's rhetoric is grafted loosely on what Steven Mailloux calls "rhetorical hermeneutics," which combines close reading of an act of textual interpretation with a rhetorical analysis of the "cultural conversation" in which this act participates. ${ }^{5}$ This approach seems warranted by the footnote itself, as the most striking question it begs is why critics "with methods and purposes so different" would find themselves working on the exact same poem at the same time. Chance occurrences are, of course, bound to take place in a field where a substantial group of people is working on a fairly limited canon of poems, but the coincidence of vision Brooks notes between both essays, as well as the somewhat mysterious prediction that they might be received by "some critics" as "overingenious" suggest factors beyond mere chance. Rather, Brooks's appropriation of Burke was part of a larger debate on the relation between literature, history, and scholarship—a debate that 
acquires new interest and relevance as today's scholars are once again assessing the value and limits of historical thinking in accounting for the distinctive features of poetry and poetic language.

Brooks's thrust at the apparatus of the traditional literary scholar in "History without Footnotes" was part of a discussion on the relation between literary studies and history that moved to the center of critical debate in a lecture by Allen Tate, delivered at Princeton University in 1940 and published in that year's autumn edition of American Scholar as "Miss Emily and the Bibliographer." In his speech, Tate accuses the bibliographer (a hypernym for the philological and historicist approaches of the nineteenth-century type) of being even more delusional than the protagonist of William Faulkner's A Rose for Emily, a deranged spinster who continued to sleep with the body of the lover she poisoned to prevent him from leaving. Both Emily and the scholar, Tate sneers, cannot bear to face their object of desire as a living, breathing entity; yet whereas mad Emily's morbid longing draws her back to her dead beau every night, the scholar moves away from the text as a literary entity. Scrutinizing its material incarnations in order to uncover its biographical or sociohistorical origins, the bibliographer dissolves the text into an assemblage of historical sources which are held to offer access to the past. His eyes crusted with archival dust, the literary historian "cannot discern the objectivity of the forms of literature, he can only apply to literature certain abstractions which he derives, two stages removed, from the natural sciences; that is to say he gets these abstractions from the historians who get them from the scientists." 6

Steeped in a line of neo-Kantian aesthetics that considered art and science to be epistemologically distinct fields of knowledge, ${ }^{7}$ Tate was highly suspicious of the bibliographer's positivist pretensions, which he considered symptomatic of the growing influence of scientism in the humanities in general. History, Tate claims emphatically, is idiomatic, brought into being through the imaginative labour of selecting and arranging historical particulars into narrative sequences. The historical method, however, denies this primary dialectic at the basis of historical experience by interjecting a set of autotelic procedural models between the historian and his materials. While these supposedly guarantee the objectivity of the account, in reality they create an ontological barrier between the historian (subject) and the past he studies (object). Dissociated from lived, concrete experience, historiography becomes an abstract and aimless exercise of the intellect that is indifferent to the values of a work of art. ${ }^{8}$ The domesticated Rankean paradigm Tate finds dominating the fields of history and philology imposes a generalizing and conceptual epistemological framework that is wholly alien to the 
subjectivist, ${ }^{9}$ intuitive knowledge the literary text embodies; these procrustean tendencies of "method," he contends, must be overcome through the "Historical Imagination," which relies on affective understanding, stressing the narrative character of historiography and restoring man to the position of a conscious agent exercising a process of selection and evaluation. ${ }^{10}$ Through the use of the Historical Imagination, the historian's vantage point in the present merges with the past, a process that results in an organic reappropriation of the knowledge contained in it:

We must judge the past and keep it alive by being alive ourselves; and that is to say that we must judge the past not with a method or abstract hierarchy but with the present, or with as much of the present as our poets have succeeded in elevating to the objectivity of form. For it is through the formed, objective experience of our own time that we must approach the past; and then by means of critical mastery of our own experience we may test the presence and the value of form in works of the past. (MEB 459)

T. S. Eliot's ideas on the relation between writer and canon clearly resonate throughout this passage: like Eliot's "Tradition," Tate's Historical Imagination manifests itself as a deep-felt, continuous, and synchronic presence that crystallizes in the concrete linguistic form of the poem and acts as a moral and aesthetic guide for literary judgment. Shifting the object of literary studies from the poem's individual historical content to its transhistorical form, Tate suspends the chronology of genres and works that served as the backbone of pretwentieth century historicist criticism and philology.

The uproar in academic circles that ensued as a result of Tate's bold speech prompted a group of critics associated with the "New Criticism" (John Crowe Ransom would coin the term about a year later) to publish Literature and the Professors in order to define a common stance on the relation between history and literature ${ }^{11}$ Among the contributors to the symposium was Cleanth Brooks, whose "Literary History vs. Criticism" locates the opposition between historicist-scholarly and formalist-critical approaches primarily on the level of poetic language. Positivist historicism, favouring content over form, considers the distorted referentiality of literary texts to be problematic with regard to criteria of empirical verifiability. Those aspects that grant the text its specifically literary character are habitually brushed aside; the historian's scientist bias results in a quantitative approach that is unable to recognize the inner structure of poetry and drama as being qualitatively different from that of referential language. Unlike Tate, Brooks frames the inability of the literary historian to deal with the poetic medium as an epistemological-rather than a moral-incapacity, but like his Agrarian friend, he feels that the 
reason for historicism's inadequacy in the field of literature is, ultimately, ontological. Poetry contains a form of knowledge that belongs to a different order of being, one that the nomothetic bias of the historian prevents him from seeing. The wealth of contextual information, statistical data or biographical conjectures that the historian routinely summons may create what Roland Barthes has called l'effet de reel; in fact they are merely so many spells meant to ward off the realization of this failure.

This brief rhetorical history of the early New Criticism's antihistoricist rhetoric outlines the basis of Brooks's antipathy towards the scholar's mechanics, and explains why he would single out the footnote as the symbol par excellence of historicist scholarship. Shored against the ruins of a failing method, the footnote embodies both the historian's penchant for piling up trivia, as well as the cumbersome and often hermetic apparatus through which this information is elevated to the status of meaning. To Brooks, the footnote is not the index of critical discipline, but the hallmark of historicist pedantry. Furthermore, Tate's polemic complicates the received notion that the New Criticism advocated an absolute separation between the text and the extraliterary world. ${ }^{12}$ The Agrarian intervention in the debate on the relation between poetry and its historical matrix is inspired, as Douglas Mao phrases it, "not by some axiomatic desire to "protect a quasi-religious, ontological sanctuary from all secularizing discourses that would situate literature in history'. . . but rather by anxieties provoked by history itself, where history seems a tale of the ever-expanding reach of science."13 This anxiety did not result in an irrational flight from history but, on the contrary, generated an intense intellectual effort to redraw the boundaries of its study. "History without Footnotes" is best understood as an attempt toward a hermeneutic that would do justice to the qualitative difference of the historical knowledge poetry contains.

If my short sketch of the background against which Burke and Brooks published their essays does not readily facilitate our understanding of the motives behind the curious footnote that is the focus of this essay, neither does it clarify why both essays would take Keats's "Ode on a Grecian Urn" for their subject. Both questions are, however, closely related to the critical program embedded in Tate's spatial reconceptualization of the bibliographer's chronologic approach. The ultimate end of the Historical Imagination was to provide a litmus test to determine the aesthetic worth of different literary species. Romantic poetry did not fare well in this evaluative undertaking, which Tate conceived primarily as a search for aesthetic opposition against the moral and cultural deprivation of modern technocratic society. Relying on individual emotion, the poet fails to imbue his poetry with what Tate calls the "creative spirit": the 
integration of the personal, cultural and aesthetic in the living historical imagination. The weakness of Romanticism, he writes,

is that it gave us a poetry of "poetical" (or poetized) objects, pre-digested perceptions; and in case there should be any misunderstanding about the poetical nature of these objects, we also got "truths" attached to them-truths that in modern jargon are instructions to the reader to "respond" in a certain way to the poetical object, which is the "stimulus." And in the great body of nineteenthcentury lyrical poetry—whose worst ancestor was verse like Shelley's "I arise from dreams of thee"-the poet's personal emotions became the "poetic stimulus." The poem as a formal object to be looked at, to be studied, to be construed . . . dissolved into biography and history. (Italics mine $)^{14}$

Against the backdrop of the imposing masculinity of Eliot's Tradition and the moral exigency of Tate's Historical Imagination, the Coleridgean doctrine of subjective imagination comes off as a pale and effeminate surrogate. The dissociation of sensibility that set in somewhere around John Milton and John Dryden had fragmented the classicist unity of image and idea, replacing its time-tested categories for judgment with a radical and eclectic individualism. The result was a dangerous historical relativism that celebrated the particularist character of historical events over their translation into formal essence. Unable to connect with the imaginative resources of transhistorical knowledge, the poet succumbs to the siren call of positivism; unlike the dynamic of tension at work in metaphysical poetry, where "the varieties of ambiguity and contradiction possible beneath the logical surface are endless," nineteenth-century English verse is a poetry of communication, used "to convey ideas and feelings that . . could be better conveyed by science."15

Stressing that meaning in poetry is continuously delayed by the oscillation between extension (its syntagmatic, metonymic axis, the development of a meaningful argument) and intension (its metaphorical, paradigmatic axis that forecloses straightforward interpretation), Tate argued that criticism, in order to do justice to the unique dynamic between both in each individual poem, is necessarily and deliberately antimethodological. Brooks, however, argues that the resultant markers of poetry's linguistic indeterminacy-metaphor, symbol, ambiguity, and paradox — can be subsumed under the master trope of irony. ${ }^{16}$ Both literary device and poetic effect, irony is the "obvious warping of a statement by the context," the structural principle which defers the meaning of individual statements to the surrounding poetic tissue, a process of synthesis that results in the elimination of friction and that confers a sense of balanced integrity on both poem and reader. ${ }^{17}$ To Tate, both literature's elusive play of meaning and the essential subjective nature 
of the historical imagination foreclose the application of fixed standards for interpretation; for Brooks, however, the ironic structures that operate in literary texts open up at least the possibility of a unified hermeneutic. That principle, the reading of Keats's ode is made to demonstrate, is that of "dramatic propriety": "suppose that one could show that Keats's lines ... constitute a speech, a consciously riddling paradox, put in the mouth of a particular character and modified by the total context of the poem. ... In such case, should we not have waived the question of the scientific or philosophic truth of the lines in favour of the application of a principle curiously like that of dramatic propriety? I suggest that this principle is the only one legitimately to be invoked in any case" (91). Although Brooks's prediction about the "overingenious" quality "some critics" might attribute to his close reading of Keats is usually taken to address historicist scholars, it seems more likely to pertain to those fellow formalists for whom the attempt to formulate a general hermeneutic principle seemed to draw the danger of reductionism closer. It was, however, not so much Brooks's methodological innovation which he expected to spark controversy, as the fact that he put it to use on a Romantic poem. For those who, like Tate, sided with Eliot's contention that the unity of thought and feeling found in Jacobean art was only regained in Symbolist poetry, Brooks's attempt to bridge "the interval between Donne and Yeats" when there was "a shrinkage in the range and depth of Western man's experience" was a highly controversial move. ${ }^{18}$ Framing its message about aesthetic perfection and historic truth as a discovery made by a single speaker, engaging on a direct and intimate level with its bearer, Keats's ode epitomizes the radical, Protestant individualism so despised by the classicist and Catholic-conservative criticism of Eliot. Although Brooks proceeds carefully when taking his distance from the latter's depreciative comments on the Ode's idealist closing stanzas, ${ }^{19}$ "History without Footnotes" is a clear attempt to break away from the narrow canon promoted during the early years of the New Criticism. ${ }^{20}$

It is tempting to attribute biographical roots to Brooks's remarkable demarche: the Ode's message of aesthetic redemption, delivered by the urn when the speaker is teased "out of thought" and surrenders to its timeless beauty, would have held an intuitive appeal to the son of a Methodist minister. But however personal, his efforts to recuperate Romantic poetry for criticism also signal the shift from the regional, reactionary modernism of the Agrarians to a broad pedagogical protocol that would become a standard in literary education. The dramatic method of exegesis that "History without Footnotes" proposes offered both immediate and practical applicability: it could be performed by any able reader, regardless of previous education or inauguration in 
instrumental fineries of philology, and did not require the availability of scholarly libraries and manuscripts. At the same time, it transformed Tate's Historical Imagination into a seemingly open and pluralist method, while its Protestant ideological overtones (a firm belief in the power of the individual, emphasis on close textual scrutiny that yields aesthetic and historical knowledge as a form of grace) guaranteed its successful absorption into the curriculum of Ivy league universities. If literary studies habitually looked across the Atlantic for guidance (whether to Germany for examples of historical scholarship or to Britain for critical axioms), "History without Footnotes" offers a confident, pragmatic, and thoroughly Americanized criticism that would quickly rise to prominence as the G.I. Bill flooded colleges with young men who lacked previous education in the arts. Still, in 1943, Brooks eagerly welcomed all those who would corroborate his dramatic methodology-controversial not just for its deliberate vulgarization of poetry to include any linguistic entity with irony as an organizing principle, but also because it downplays the agon between science and poetry that is vital to Tate's Historical Imagination in favor of a more unified literary hermeneutic and a more confident conception of literature's power (as historian). The near simultaneous publication of Burke's essay on Keats, then, must indeed have been a bracing occasion-especially since Burke announces his own "dramatistic" reading to focus on the ode's emblematic but contested closing statement that "Beauty is truth, truth beauty, - that is all / Ye know on earth, and all ye need to know." ${ }^{21}$ Like Brooks, Burke claims that the lines stage an opposition between practical (scientific) and aesthetic (poetic) ideals, an opposition which is reflected in-and ultimately transcended through-the development of the poem's imagery.

The scope of the dramatistic methodology Burke deploys for his reading of the ode, however, differs decidedly from that of Brooks. Burke readily uses the kind of information one would expect to appear in traditional biographical criticism: a significant part of "Symbolic Action in a Poem by Keats" is devoted to the tubercular fever that plagued the poet, its impact being traced in other poems ("On Seeing the Elgin Marbles," "On First Looking into Chapman's Homer”), and fragments of the letters to Fanny Brawne are cited as indications of its presence in the mind of the poet. As a general principle, Burke urges readers to "use whatever knowledge is available" in order to resist the intellectual limitations of a factional opposition between approaches where "semantic meaning, that may be considered as a partial aspect of poetic meaning, tends to become instead the opposite of poetic meaning, so that a mere graded series, comprising a more-than and less-than, changes instead to a blunt battle between poetry and anti-poetry, 'Poetry vs. Science'" 
(451)..$^{22}$ In order to overcome the dualism between scholarly and critical approaches, Burke developed a conceptual apparatus that would enable a more inclusive analysis of the poetic substance they share, which he divides into three levels: Dream (the unconscious or subconscious factors in a poem, both personal, cultural, and archetypal), Prayer (the rhetorical mechanics deployed to communicate a poem to the reader and induce a certain response), and Chart (the "sizing-up" of a historical situation) ( $P L F 5-6)$.

Against his formalist contemporaries, Burke ties poetry to the real, acknowledging that "whatever 'free play' there may be in aesthetic enterprise, it is held down by the gravitational pull of historical necessities: the poetic forms are symbolic structures designed to equip us for confronting given historical or personal situations." ${ }^{23}$ Deploying a Freudian terminology of displacement and condensation on the level of Dream, however, his argument moves against the naïve verbal realism of positivist historicism, as well as causalist theories of behaviorist science and Marxist theories of economic determination. The poetic medium unites different degrees of referentiality through a series of fluid connections: the "frozen kiss" of the "Bold Lover" that is "all breathing human passion far above," for instance, can betray an unconscious equation of sexuality and bodily decay that is, in turn, symptomatic of a larger social unconscious: the Romantic identification between sexuality and the death drive. On the level of Prayer, however, it takes part in the binary oppositions (motion-stillness, death-life, sound-silence, etc.) that coax the reader into accepting the claim that "beauty is truth, truth beauty," while on the level of Chart the image connects with the respiratory difficulties related to Keats's tubercular fever, as well as reaching out to the cultural fabric by accommodating the aesthetics of nineteenth-century Graecophilia. The poem, then, offers highly divergent ways of entry for the aspiring critic, including biographical, psychoanalytical, and especially historical, none of which can be excluded in advance from the domain of critical scrutiny.

Burke stresses this point repeatedly throughout "Symbolic Action in a Poem by Keats," apparently making the essay an unlikely support for the ascholarly, intrinsic method that Brooks advocates. It would be misguided, however, to claim that every corner of Burke's triad is allotted equal critical weight. The rhetorical dynamics of the poem, the level of Prayer, takes precedence over its Dreams and Charts. If no contextual information is available, Burke says, the poem can only be looked upon as "a series of internal transformations to be studied in their development from a certain point, and without reference to any motives outside [the text]" (450). However, intrinsic analysis is not just 
a makeshift strategy used in the absence of the sort of information that the bibliographer would claim for his object of study, and abandoned as soon as more becomes available. As Greig Henderson suggests, Burke gradually develops the conviction that language, the realm of the symbolic, inevitable mediates all human interaction with the real. ${ }^{24}$ Indeed, "Symbolic Action in a Poem by Keats" can be read to proclaim this belief in the ontological priority of the symbolic: "[A] poem is an act," Burke announces at the beginning of the essay, "the symbolic act of the poet who made it-an act of such a nature that, in surviving as a structure or object, it enables us as readers to re-enact it" (447). Faced with the opposition between science and art at the particular historical instance which he inhabited, Keats responded by proclaiming that art is the beall and end-all of human knowledge. What makes the ode so effective, however, is not just the imaginative power of this idea, but the fact that the poem, as a symbolic artefact that turns over against its nonsymbolic origins, unites both subject matter and procedure. Its symbolicity is what enables the ode to address us beyond the confines of its age, yet this ability for historical survival also closes it off from straightforward historicist recuperation.

Stressing this primacy of Prayer in Burke's triad would have enabled Brooks to minimize the differences between his dramatic reading and Burke's. However, I would argue that, rather than downplaying the dimensions of Dream and Chart in Burke's reading, the reconceptualization of Tate's Historical Imagination that Brooks performs in "History without Footnotes" is aimed at effacing their disruptive potential altogether. This critical move is best exemplified by Brooks's comments on the image of the "little town" that is summoned in the fourth stanza of the ode, which is apparently not depicted on the urn itself, but merely suggested by the people coming to the sacrifice. Yet despite its being beyond sensual apprehension, the poet is able to infer some of the essential qualities of the town: it is small, bucolic, and quiet, its streets having been emptied by a joyous procession. This knowledge, Brooks suggests, is not gratuitous fancy: the poet has obtained it by pursuing the logic of his own imagery. Even if there were an actual vase or series of antique freezes on which Keats modelled his poem, the imaginative trouvaille of the little town demonstrates that the poet can provide a truth that differs from the factual accuracy desired by positivist historicism. Harold Bloom, discussing the passage, has argued that " $[\mathrm{t}]$ he green altar and the little town exist not on the urn but in the past and future that are phenomenological implications of the poem's existence." 25 To Brooks, this is what is essential to the urn's characterization as a "sylvan historian": it delivers an imaginative truth that supersedes the historian's accounts 
of the contingent: "Mere accumulations of facts . . . are meaningless. The sylvan historian does better than that: it takes a few details and so orders them that we have not only beauty, but insight into essential truth. Its 'history,' in short, is a history without footnotes. It has the validity of myth-not myth as a pretty but irrelevant make-belief, an idle fancy, but myth as a valid perception into reality" (100). Brooks's equation between literary form and "true" history on the one hand and history and myth on the other, can be compared to the notion of "figural causation" that Erich Auerbach develops in Mimesis. As a mode of historicism, Hayden White argues, figural causation differs from ancient teleological notions of history as well as modern, mechanistic historicism in the kind of relation it supposes between historical events. What Auerbach suggests is "a history conceived as a sequence of figure-fulfilment relationships" in which "[t] he later events are not 'caused' by earlier ones, certainly not 'determined' by them. Nor are the later events predictable on any grounds of teleology as realizations of earlier potentialities. They are related in the way that a rhetorical figure, such as a pun or metaphor, appearing in an early passage of a text, might be related to another figure, such as a catachresis or irony, appearing in a later passage." ${ }^{26}$ As a series of tropological connections, history as both process and practice folds into the literary: the claims that positivist historians make with regard to the representation of the past are merely one species of literary rhetoric taking part in the metahistory of mimetic desire that underlies Auerbach's work. In quite similar fashion, the structures of irony that Brooks finds operating on the level of the image find their fulfilment in the poem as an organic whole, which in turn appears as a synecdoche of the broader horizon of the transcendental literary "Imagination" that is the foundation for all nondiscursive historical knowledge.

Both Auerbach and Brooks espouse a formalist conception of history, but whereas the concept of figural causation enables Auerbach to relate literature and context by seeing the text as a "figuration" of its historical milieu, in Brooks's criticism, the synecdochic relations between irony, history, and imagination merge into an opaque, organic whole, a "silent form" that is impervious to attempts at chronological separation or paraphrase. Auerbach's indexical formalism enables critics to access the realm of the historically real; Brooks's aesthetic alternative allows only a vision of poetic universals. ${ }^{27}$ If Tate's critique of literary historicism was rooted in a Manichean antithesis between poetic value and scientific truth, Brooks's aesthetic historicism no longer projects science as an outside: by "teas[ing] us out of thought," the poem-as-myth offers a knowledge that supersedes all other, fragmentary discourses that inform it. To be sure, Brooks acknowledges that poetry has sociohistorical or 
psychobiographical origins, nor does he deny that the bibliographer might contribute to our understanding: in its nature as myth, however, poetry simply ceases to be a medium through which these dimensions can be mediated or engaged. If we recall the ongoing dualism in Brooks's own practice as a student of literature, this way of solving the problem of the extrinsic is hardly surprising. If contingent history yields to poetic myth, advocating a formalist, acontextual strand of criticism while devoting a significant part of one's career to footnote-laden philological labour of editing the letters of the eighteenth-century bishop and literary antiquarian Thomas Percy ceases to be a schizophrenic position: the sublime discourse of poetry already "contains" both within itself. ${ }^{28}$ Provided that the structural hierarchy in which intrinsic analysis precedes extrinsic speculation is preserved, they may each yield their own kind of hermeneutic satisfactions. ${ }^{29}$

Each poem, then, is like the "peaceful citadel" in the ode, a paradox which "involves a clash between the ideas of war and peace and resolves it in the sense of stability and independence without imperialistic ambition-the sense of stable repose" (97). The corresponding attitude is one of disinterested contemplation: Brooks conjures the reader not to be overwhelmed by the initial, fragmentary strangeness of the poetic material, but to look for imaginative unity. Like Wallace Stevens's voices at Key West, dramatic readings confer the idea of order and subdue the shiver of history a reader may experience when confronted with the historicity of the poem. Personal interests or desires, then, are merely the hysteria of a Southern spinster, an affective fallacy committed silently at the edge of the community of righteous readers; mimicking the formal perfection of their object of study on both the levels of form and content, Brooks's essays offer themselves to the reader as just such peaceful citadels of knowledge. The footnote, the index of a differential whose visually disjunctive presence on the page bears witness to the interaction of a historical reader with the text and summons the possibility of other, extrapoetical levels of textuality, opposes this totalizing hermeneutic. However, by claiming for poetry a transcendent, mythic totality that includes every difference within itself, "History without Footnotes" manages to clear a space where the corrosive potential of the scholarly apparatus can be absorbed. Jerome McGann has remarked that Brooks's footnotes "are all decidedly unscholastic: leisurely, self-referential, or digressive discussions or brief cross-references." ${ }^{30}$ As I have tried to demonstrate, however, when pressured by deliberately historicizing, some of these casual gestures can be revealed to mask a definite rhetorical content in the form of a careful strategy of recuperation and containment. The seemingly cordial reference to Burke enlists his reading of the ode as an 
ally against potentially averse reactions on the part of critics like Tate, while at the same time Burke is displaced to a medium whose contribution to the overall meaning of the text is-Brooks makes abundantly clear-at best secondary.

But why would Brooks choose this roundabout way to acknowledge Burke? After all, stressing the primacy of Prayer, Burke's dramatism does seem highly convergent with Brooks's principle of dramatic propriety. When we insist that language - the symbolic - is the ultimate ontological horizon of the human, the psychobiographical and cultural-historic dimensions of the poem cease to be forces of opposition against the kind of free-floating formalism that Brooks established. Burke himself expressed a continuous awareness of the relativistic tendencies inherent in his dramatist heuristic, where the dialectic between the levels of Dream, Prayer, and Chart is arrested when one element is elevated above the others. ${ }^{31}$ Such reductionist operations signal the crystallization of dynamic interrelations into teleological structures of power-Brooks's emphasis on the acquisition of mythical knowledge being a case in point. The knowledge of essentials that his dramatic reading promises to bring demands a complete suspension of disbelief on the part of its spectator, a complete surrender of the critical faculties to the poem's unified structural movement. Brooks's drama, then, appropriates the full weight of classical tragedy. Ironically, what started out as a project against the normative truths of Enlightenment modernity and the neutral objectivism of positivist science is exchanged for a similar ideal of distance.

It is this ideal of distance that the dramatism of "Symbolic Action in a Poem by Keats" negates, giving it a decidedly Brechtian quality. If it is true that the poem's nature as a symbolic act is what grants it the ability to transcend its personal and historical moment of composition, Burke reminds us that, as a symbolic act, the poem forces us to reply with an act of reading that is, like the original act of writing, historically determined. If writing poetry involves "the adopting of various strategies for the encompassing of situations" ( $P L F 3)$, our act of critical reading likewise entails stressing some elements over others. Poetry can give us knowledge about the real-both contemporary and historical-yet we must be aware that such knowledge is always momentaneous, specific, and inevitably blindsided by the limits of the perspective from which we engage it. Although Burke's analyses of symbolic structures are steeped in the awareness that nonlinguistic access to historical reality is impossible, history remains as the material and temporal substratum in which every interpretive act is grounded. Thus, Burke's drama does not gain the monolithical, tragic qualities of Brooks's: eagerly intertextual, flaunting several footnotes, and using a mobile conceptual vocabulary, "Symbolic 
Action in a Poem by Keats" embodies the comic attitude that underlies Burke's dramatism, which constantly bears witness to its awareness of its own discursive limitations.

Perhaps, then, the footnote that served as the focus of this essay illustrates not just the striking differences in both method and purpose stored under the heading of "formalism," but also the power of the Romantic lyric in shaping these different critical approaches. If Brooks sought to recuperate the "Ode on a Grecian Urn" for literary studies because it showed how the individual could transform historical particulars into nondiscursive and essential truth, to Burke the ode epitomizes the ever shifting dynamics between the demands of personal expression, contextual information, and imaginative demand at play within all poetry. Against Brooks's classical, monolithic drama, Burke's literary criticism runs along this "negative capability" (to borrow Keats's expression) of the textual and the historical reflected in both content and form of the lyric. Insisting that every interpretation is an act that inevitably entails an affective-or, as Burke would say, terministic-fallacy, it is this selfreflexive, lyrical awareness of his criticism that differentiates his formalism from that of his New Critical contemporaries, causing him to be buried in the silence of Brooks's footnote.

\section{University of Ghent / Research Foundation - Flanders}

\section{NOTES}

1 For those essays-like Brooks's-that were revised in subsequent publications, I refer to the original publication; otherwise, references are to more accessible editions or anthologies. All quotations from Burke's "Symbolic Action in a Poem by Keats" or Brooks's "History without Footnotes: An Account of Keats' Urn" are rendered by page numbers in the text; other page references can be found in footnotes. References from Kenneth Burke, "Symbolic Action in a Poem by Keats," in A Grammar of Motives (Berkeley and Los Angeles: Univ. of California Press, 1969), 447-64, and Cleanth Brooks, "History without Footnotes: An Account of Keats' Urn," Sewanee Review 52 (1944): 89-101.

2 The recent revival of Burke in critical theory seems to result in some attempts at recuperation. See David H. Richter, The Critical Tradition: Classic Texts and Contemporary Trends (New York: Bedford St. Martin's Press, 1998) and Frank Lentricchia and Andrew Dubois, eds., Close Reading: The Reader (Durham, NC: Duke Univ. Press, 2003).

3 Anthony Grafton, The Footnote: A Curious History (Cambridge, MA: Harvard Univ. Press, 1998), 9.

4 I am employing the terminological distinction that Frank Ankersmit draws between 'historism' and 'historicism' or, roughly, between a philosophy of history that maintains that events are always (partially) determined by their historical context and speculative philosophies of history that consider the past as a way of predicting the future. See Frank Ankersmit, History and Tropology: The Rise and Fall of Metaphor (Berkeley and Los Angeles: Univ. of California Press, 1994), 45-58.

5 See Steven Mailloux, Rhetorical Power (Ithaca, NY: Cornell Univ. Press, 1989). 
6 Allen Tate, "Miss Emily and the Bibliographer," American Scholar 9 (1940): 458 (hereafter cited as MEB).

7 See William J. Handy, Kant and the Southern New Critics (Austin: Univ. of Texas Press, 1963).

8 See Allen Tate, "What Is a Traditional Society?" in Collected Essays (Denver, CO: Alan Swallow, 1959): 299-302.

9 Grafton points out that Ranke, while supposedly fathering source criticism and establishing the footnote at the heart of the modern historical apparatus, entertained a deep-felt desire to return to the classical notion of historiography throughout his career and, in fact, disliked having to add footnotes-the practice of routinely adding them only became prevalent among his many disciples. See Grafton, The Footnote, 62-93 and 228-29 10 See Robert S. Dupree, Allen Tate and the Augustinian Imagination: A Study of the Poetry (Baton Rouge: Louisiana State Univ. Press, 1983), 118-19.

11 Mark Jancovich calls the impact of Tate's speech "dramatic"; George Core claims somewhat more prosaically, that "the audience could not have been more surprised and shocked had Hermann Goering's Luftwaffe bombed and strafed those sacred precincts." See Mark Jancovich, The Cultural Politics of the New Criticism (Cambridge: Cambridge Univ. Press, 1993), 97, and George Core, "Two Critics," Virginia Quarterly Review 65, no. 1 (1989). 12 Eagleton's claim that the New Critical program of "rescuing the text from author and reader went hand in hand with disentangling it from any social or historical context" is perhaps most often invoked as an example of this view. Eagleton himself, however, modifies this extreme position, stressing that the New Criticism "stopped short of a full-blooded formalism." See Terry Eagleton, Literary Theory: An Introduction (Oxford: Basil Blackwell, 1983), 47-48.

13 Douglas Mao, "The New Critics and the Text-Object," English Literary History 63, no. 1 (1996): 234.

14 Tate, "Understanding Modern Poetry," in Collected Essays, 121.

15 Tate, "Tension in Poetry," in Collected Essays, 77-80.

16 I am stretching chronology here a bit: Brooks did not single out "irony" in The Well Wrought Urn, using "paradox" to designate both individual instances of the trope and the overall quality of the language of poetry. As a concept, irony crystallized only in "Irony as a Principle of Structure" (1951). However, I feel justified using it here for the sake of clarity, as the former essay clearly connects irony to the dramatic hermeneutic propagated in "Keats's Sylvan Historian."

17 See Brooks, "Irony as a Principle of Structure," in The Critical Tradition: Classic Texts and Contemporary Trends, ed. David H. Richter (Boston: Bedford, 1998).

18 See, for instance, Tate's response in "A Reading of Keats," in Collected Essays, 138. Brooks's canonical salvage job is embodied clearly in The Well Wrought Urn, which frames readings of Shakespeare, Milton, Thomas Gray, and others between John Donne's "Canonization" and W. B. Yeats's "Among School Children."

19 See T. S. Eliot, "Dante," in Selected Essays (London: Faber and Faber, 1999), 270: "[O]n re-reading the whole ode, this line strikes me as a serious blemish on a beautiful poem; and the reason must be either that I fail to understand it, or that it is a statement which is untrue. And I suppose that Keats meant something by it, however remote his truth and his beauty may have been from these words in ordinary use. And I am sure that he would have repudiated any explanation of the line which called it a pseudo-statement." 20 Sauerberg reminds us that "Eliot's criticism, although usually taken to revolve around a handful of dogmatic pronouncements, is by and large a kind of discursive criticism which is only seldom not derived from a specific text under consideration, and then expressed in a way which always leaves ample room for discussion by an equally capable critic." See Lars Ole Sauerberg, Versions of the Past, Visions of the Future: The Canonical in the Criticism of 
T. S. Eliot, F. R. Leavis, Northrop Frye and Harold Bloom (Basingstoke, UK: Macmillan, 1997), 30 .

21 It is not unthinkable that Brooks's "dramatic propriety" and Burke's "dramatism" are the result of an intellectual crossover: in January 1937, Burke sent Cleanth Brooks the manuscript of Attitudes toward History, which contained the core of what would eventually develop into dramatism. See Ann George and Jack Selzer's informal chronology of events in Burke's life. Jack Selzer and Ann George, Kenneth Burke in the 1930's (Columbia: Univ. of South Carolina Press, 2007), 220, and their discussion of dramatism in Attitudes toward History, 161-63.

22 Burke, The Philosophy of Literary Form: Studies in Symbolic Action (Baton Rouge: Louisiana State Univ. Press, 1941), 139 (hereafter cited as PLF).

23 Burke, Attitudes toward History, vol. 1, The New Republic Dollar Series (New York: New Republic, Inc., 1937), 73

24 See Greig H. Henderson, Kenneth Burke: Literature and Language as Symbolic Action (Athens: Univ. of Georgia Press, 1988), especially the chapter on "Words and the Word."

25 Harold Bloom, The Visionary Company: A Reading of English Romantic Poetry (Ithaca, NY: Cornell Univ. Press, 1971), 418-19

26 Hayden V. White, "Auerbach's Literary History: Figural Causation and Modernist Historicism," in Literary History and the Challenge of Philology: The Legacy of Erich Auerbach, ed. Seth Lerer (Stanford, CA: Stanford Univ. Press, 1996): 128.

27 I'm employing the useful distinction between "indexal" and "aesthetic" formalism made by Richard Strier. See Richard Strier, "How Formalism Became a Dirty Word, and Why We Can't Do without It," in Renaissance Literature and Its Formal Engagements, ed. Mark Rasmussen (New York: Palgrave Press, 2002), 210.

28 The first volume of The Percy Letters (which Brooks coedited with David Nichol Smith) appeared-not so coincidentally_in the same year as "History without Footnotes."

29 See, for instance, the epilogue to Brooks, Historical Evidence and the Reading of SeventeenthCentury Poetry (Columbia: Univ. of Missouri Press, 1991).

30 Jerome McGann, Social Values and Poetic Acts: The Historical Judgment of Literary Work (Cambridge, MA: Harvard Univ. Press, 1988), 51.

31 See the essay on the "Four Master Tropes" in the appendices to A Grammar of Motives. 